\title{
A Well-Conceived Vision for Extending Professional Life of Seniors
}

\author{
Hamideh Afsarmanesh ${ }^{1}$, Luis M. Camarinha-Matos ${ }^{2}$, and Simon S. Msanjila ${ }^{1}$ \\ ${ }^{1}$ Informatics Institute, University of Amsterdam, Science Park 107, \\ 1098 XG, Amsterdam, The Netherlands \\ $\{$ h.afsarmanesh, s.s.msanjila\} @uva.nl \\ ${ }^{2}$ Faculty of Sciences and Technology, New University of Lisbon, \\ Quinta da Torre, 2829-516, Monte Capatica, Portugal \\ cam@uninova.pt
}

\begin{abstract}
A fundamental challenge related to enhancing the active life of senior professionals is to identify ways to assist promoting the role of elder people within the continuously ageing European society. One approach to achieve this purpose is to establish a support environment which shall provide fundamental assistance to senior professionals to fully use their expertise and experience to continue delivering professional services to the society. A well conceived vision need to be established to guide the society towards achieving this goal. This paper presents the first vision statement and its instantiations for enhancing the active life of senior professionals in the European society. It first proposes an approach for building the vision.
\end{abstract}

Keywords: Visioning, multi-perspective vision, professional active life.

\section{Introduction}

The main concerns about population in the twentieth century were around the growth of population and the consequences on resource scarcity. However, the forecasts for the $21^{\text {st }}$ century introduced some other new concerns, primarily focused on the ageing population and the overloaded pension systems. In several parts of the world the decline in birth rate seems to have reduced some of the severity of the problems related to scarcity of natural resources. Nevertheless, the main concern today related to the population, which is becoming even more serious in developed countries such as those located in Europe and North America, is the rapidly ageing population.

As the Europe's population ages the number of those who are of working age (defined as 15-64) becomes smaller in relation to those of 'non-working' age who are usually referred to as economic "dependants" [10]. The challenge of coping with this trend is now dominating Europe's attitude to population policy and if relevant measures are not put in place for this problem then the following example problems might occur in the European society:

Economical difficulties: Severe economical difficulties will rise for the pension system in Europe, in relation to supporting the life of this large group of retired people. 
Traditionally, the life of elder people was supported through pension systems, which relied on the taxes paid by the workers active at the time. Today, but more steeply in the coming decades, the pension systems are becoming overloaded, as on one hand the number of people who shall receive benefits increases, while on the other hand the labour force and thus the number of tax payers gradually decreases.

Lack of human resources: Harsh economical challenges will be faced increasingly at the workplace by the lack of qualified human resources, since every year a very large group of ageing population retires. One recent promising approach to address the challenge of dealing with the ageing population in Europe looks into the possibility of extending the involvement of senior professionals who are willing to do so in the ongoing activities in market and society.

A number of approaches and initiatives are now applied to support elders remaining professionally active and thus continue their participation in daily activities and by so doing contributing to addressing the above problems. The participation of elder professionals is either in individual manner or in some sort of communities. Applying the concepts of collaboration as inspired in the discipline of collaborative networks [1], the communities of senior professionals are established either as long-term strategic alliances (Community of Active Senior Professionals - CASPs) that are configured to enhance preparedness of senior professionals (SPs) towards actively participating in daily activities or as short-term networks (Teams of Senior Professionals - TSPs) that are configured to respond to a specific opportunity. Although there are a number of initiatives in Europe that are aiming at supporting seniors to remain professionally active, there is still no common focus regarding the future participation of seniors in societal activities. A well-conceived vision capturing fundamental aspects on future active life of elder people needs to be constructed.

This paper presents a systematic visioning approach and presents a vision which is built using the proposed approach and aimed at supporting extending Professional Active Life (ePAL) of elder people in Europe. The vision is instantiated into three perspectives of technological, organizational and social.

\section{Base Concepts Related to Vision}

Visioning is an important aspect for leadership, strategy implementation and change [8]. The application of vision in defining and shaping the future direction of an organization or a society is increasingly becoming popular in today's world. A vision defines a desired future, while strongly interconnected with the framework that underlies the organizations or societies [3]. It is a deeply held picture of where a person, a group of people, an organization, or a society, wants to reach in the future.

A vision, a compelling view of a future yet to be, creates meaning and purpose which catapults both the people and the society to high levels of achievement [5]. We create meaning in our lives by pursuing our future visions, and we refine our visions based on the meaning we are discovering through our experience. A vision is the most inspiring future the society can imagine. Because of this, the society can never truly achieve its vision. It works toward that vision. The societies' visions communicate to others who they are and who they want to become and not what they have achieved. A vision for a society shall provide the following: (1) Compelling image of the future, 
(2) Credible and attractive view of what is potentially feasible for the society, (3) Unifying guides to what the society wishes to and can become, and (4) Inspirational focal point for the spirit of the society and its members.

A well-conceived vision consists of two major components, namely, the core ideology and the envisioned future [4]. Core ideology is the first primary component of the vision framework which consists of two parts: core values and core purpose. Core values are the essential and enduring tenets of an organization or a society - a small set of timeless guiding principles that require no external justification. Core values have intrinsic value and importance to those inside the organization or society. Core purpose however points to certain fundamental reason for society to exist. An effective purpose reflects the importance that people attach to daily activities of the organization or society. Envisioned future is the $2^{\text {nd }}$ primary component of the vision framework which consists of 2 parts: a long-term audacious goal and a vivid description of what it will be like when goals are achieved.

Visioning process is one of the least straightforward, yet most important, concepts that enable influencing the future, and building successful organizations and societies. The cornerstone of a vision is a clear image of how the society will satisfy important stakeholders' needs. It is important that the vision is built from what stakeholders perceive to satisfy their needs not what the providers (government, non-government organizations, regulatory bodies, etc.) think will satisfy them. This requires an extensive interaction with all stakeholders in the society in order to perceive the needs from stakeholders' perspective. It should be noted that visioning differs from the common estimation practice related to understanding the possible future situations - forecasting. Forecasting is the process of performing an estimation of unknown situations related to certain aspect of the society. Nevertheless, while formulating a vision and when it is needed to estimate some possible future situation, forecasting can be used as a tool in visioning process, such as in understanding the societal drivers and trends as well as possible future scenarios (see further in section 3 ).

\subsection{Related Visions for ePAL Environment}

A number of initiatives such as research projects have been carried out in Europe addressing different aspects related to ageing well. Most of these initiatives see SPs as recipient of services from the market and ineligible to continue participating in societal activities. As a result, there is a lack of models or regulations guiding elders' participation in value creation activities. Consequently, the European society has been loosing or misusing the massive knowledge and experience possessed by these elders especially those who were involved in professional employments. Furthermore, after retirement most SPs feel lonely, isolated and useless to the society although they are sure that they possess both the knowledge and experience that their society is in need.

Senior professionals have been trying to remain active in the European society by volunteering to perform certain activities. Such volunteering has been realized either by individual initiatives or through certain associations of senior professionals. At present, a number of associations are established for senior professionals in some regions of Europe. They aim at supporting individuals and teams of individuals either to provide services which are lacking in the market or to address specific beneficiaries not dealt with by normal market actors, and thus there is no competition or conflict 
with business organizations. They also aim at providing services to some categories of organizations, e.g. those that cannot afford buying such services in the market.

To coordinate its activities towards aimed future, each of these associations has either explicitly or implicitly (in form of policies or mission) stated a vision. Below we present four example statements that are expressed by associations of senior professionals as their vision or mission (source: www.epal.eu.com)

SEN@ER - Silver Economy Network of European Regions: perceives that it is needed to consider demographic change and the ageing of European society as both a challenge and an opportunity for economic growth and improving competitiveness. Its vision states: "Increased social inclusion of and improved quality of life for older people, employment and job creation in the regions increase of competitiveness".

PUM - Netherlands Senior Experts: addresses service provision in developing countries, founded on the base of free knowledge and experience offered by its SPs: "Practical and business-like: helping small and medium-sized businesses stand on their own two feet is more effective than theorizing and moralizing".

ASEP - Austrian Senior Experts Pool: Under the umbrella of "Net of experts", ASEP believes that nowadays the "retirement phase" is being addressed and treated as a separate phase of life. The engagement of elderly people within the family and within honorary voluntary jobs (activities) gives this phase of life a greater meaning. Members of ASEP aim at passing their experience, knowledge and competence free of charge to the community while realizing the concept of a $3^{\text {rd }}$ phase of life, which is characterized by health, activity and service to the community.

ASECAT - Asociación de Expertos para la Cooperación y Asesoría: With the slogan "be voluntary", the ASECAT association, using the knowledge and experience of its professional seniors, gives voluntary advice, assistance and administrative services to entrepreneurs and businesses with lower incomes. Its main objective is to contribute to the society in generating value, improving the conditions of life, and promoting the socio-economic development.

As it can be observed from the above statements these visions guide associations towards providing services on voluntary basis. As a result, few SPs are motivated to join such associations. Thus a number of aspects need to be addressed and included in a vision that shall guide the European society towards a better active life of elder people and better sharing of benefits for their participation in value creation activities.

\section{Systematic Building of the ePAL Vision}

There are two schools of thought when it comes to developing a vision for the society to address a particular aspect of a society in order to transform it to a better desired future situation. On the one hand vision building is believed to be the responsibility of the leadership of societies to develop and articulate a powerful vision. On the other hand, it is advocated that all 'stakeholders should together support what a society wants to achieve in future. Therefore, according to this second school, vision should be co-created by its stakeholders across the society. 
In this paper, we perceive that none of these schools of thought are completely wrong or completely right for developing a vision for a part of the society! There is a case for the role of leadership in developing and articulating a vision. However, also all stakeholders must be involved to tune and re-define the vision by incorporating their interests and to commit themselves on providing support towards achieving the envisioned future [9]. It is challenging to properly involving both stakeholders and leaders in a coordinated manner while formulating a well-conceived vision for the ePAL. Another challenge is related to the identification of fundamental aspects that need to be included in the vision. A well-conceived vision can hardly be formulated in random and ad hoc manner. Therefore, there is a need for having a systematic approach to guide all steps that must be performed and the stakeholders that must be involved in such process.

We propose an approach for building a vision with involvement of stakeholders at different stages, providing a general step-wise guidance for the process of building a vision for an environment. To enhance the clarity of presentation of the proposed approach in some steps we provide examples related to vision construction for ePAL environment. The approach has five steps as shown in Fig. 1, namely: (1) Discussion and generation of visionary ideas for the environment, (2) Elaboration of $1^{\text {st }}$ vision, (3) Testing and validating the elaborated vision, (4) Consensus building through consulting and workshop, (5) Documenting and finalizing the vision.

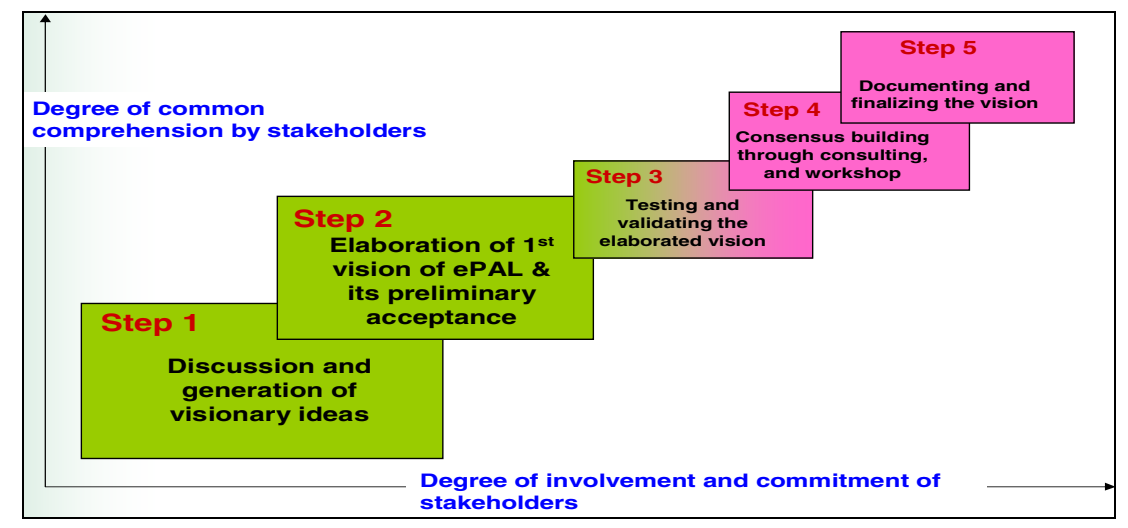

Fig. 1. Generic steps for building a vision, involving main stakeholders

The first two steps are the main steps in this process, performing the large analysis of many aspects and elements of the ePAL environment (Step 1), and analyzing all collected results to extract and build the $1^{\text {st }}$ vision of ePAL and reaching preliminary expert consensus on the vision (Step 2).

Step 1: Discussion and generation of visionary ideas. This step starts when the need for building a vision is realized and that some aspects of the society require systematic changes to reflect on the future life of the society. For example, this step is triggered by identification of a crisis or immediate need in the society and where its possible solutions demand changes within the society. 
A variety of people, such as decision makers and leaders, experts, research community, etc., are involved in the discussion of what elements must be addressed and/or included in the vision for the targeted environment. VOmap project has developed a so-called "vision ideas building process" [2] which is applied here. This process guides the identification of the main elements that must be addressed to build a comprehensive vision of an environment or a society, such as the vision for guiding the enhancement of active life of senior professionals (Fig. 2). The process is modelled in the style of IDEF0, addressing inputs (from left), resources and mechanisms used (from below), constraints (from above), and output (on the right).

As indicated in Fig. 2, in step 1 the process of generating preliminary vision's ideas for ePAL environment is influenced by three different types of elements/aspects, namely: (1) Input materials: Refer to existing materials that can be sources of fundamental ideas related to the ePAL vision. To build the ePAL vision some input materials that were considered and analyzed include: state of the art in literature, results of related projects, related vision and mission statements, (2) Constraints: Refer to practices that are relevant to the ePAL environment in the European society which unless properly considered and addressed by the vision may have the potential to prevent, restrict, or dictate the actions that may need to be taken to realize the vision. Example constraints that are addressed while generating vision's ideas include: laws, rules and regulations; society indicators; some practice related disruptions (such as emergence of new technologies), etc. and (3) Resources and mechanisms: Refer to the available knowledge, competencies and capabilities that can be applied to generate, analyze, and organize vision's ideas for ePAL environment. During the process of generating vision's ideas the resources and mechanisms are to be provided by the following: the research consortium (i.e. ePAL consortium), visionaries and experts in related areas, stakeholders, etc.

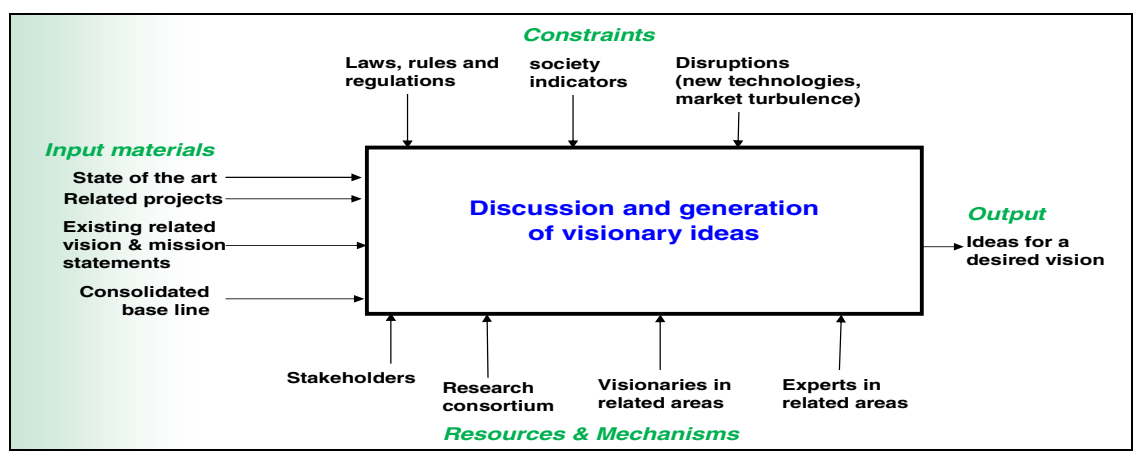

Fig. 2. Elements that need to be addressed while building ePAL vision

A number of different types of stakeholders were involved, namely through participation in a number of workshops and seminars, in the process of generating vision's ideas for ePAL environment to provide the consortium with necessary resources and mechanisms. Involved stakeholders included: (1) Representatives of communities of senior professionals, (2) Experts from different disciplines addressing enhancement of life of senior professionals, (3) Representatives of active labour 
forces in different market domains, (4) Representatives of employer organizations, (5) Visionaries in related areas, and (6) Individual senior professionals. The output of this step is a set of general visionary ideas, related to the ePAL environment, and achieving a deep understanding of this area.

Step 2: Elaboration of $1^{\text {st }}$ vision. In this step the aim is the identification and generation of the main elements related to the vision statement for the environment, based on the knowledge and experience available/gained within the ePAL consortium, the acquired understanding of the baseline and the visionary ideas generated in Step 1. This phase is extremely important - where the $1^{\text {st }}$ vision statement is established based on the analysis of the main drivers and trends, and through developing and analysing a number of scenarios (Fig. 3). Lessons learned from these studies are the constituting elements for the $1^{\text {st }}$ vision. As shown in Fig. 3, there are two fundamental processes in this step whose results are important inputs to the elaboration of the $1^{\text {st }}$ vision. It is necessary to establish and analyze drivers and trends to understand what is currently happening in the society. It is also necessary to build scenarios to understand the possible evolutions of the drivers and trends that can occur in the near future if a certain situation will have to be realized. The results of the two tasks provide an input to identifying main elements to be incorporated in the vision.

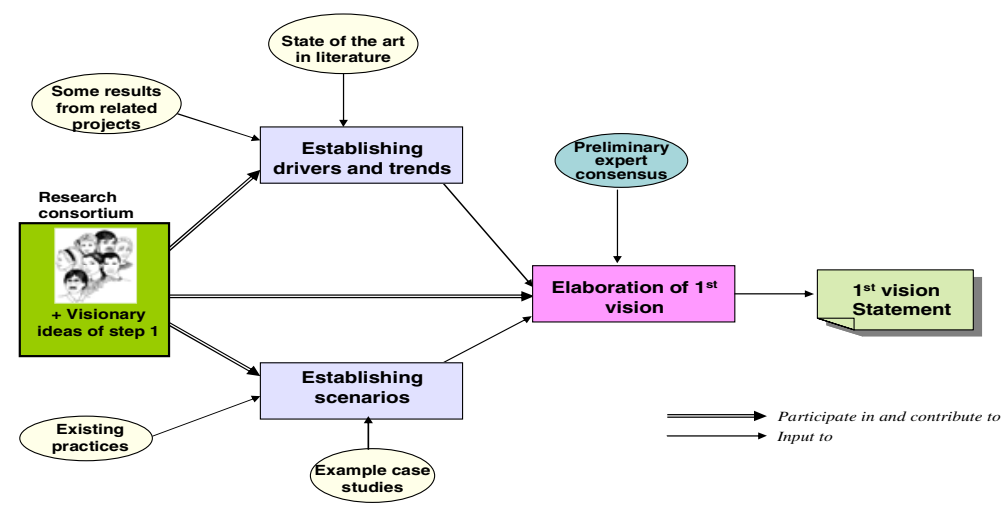

Fig. 3. Presenting and elaborating the vision ideas

Establishing drivers and trends: a fundamental prerequisite for developing a vision is to identify both drivers and trends. Drivers refer to the main influences (driving forces) which guide the running and changes of the society. Trends refer to the main happenings related to each driver. Thus trends indicate how each driver will influence the changes in the market or society. The analysis of drivers and trends enables the visionaries and researchers to identify fundamental areas or perspectives that need to be properly covered by the vision. Through extensive baseline study on achieved research results and existing practices related to ePAL we have observed that vision's ideas can be classified into three perspectives of technological, social, and organizational. As shown in Fig. 4, the categorization of main drivers is matched to these perspectives and a number of sub-drivers are identified. Furthermore, for each subdriver a number of trends are characterized. 
Establishing scenarios: Building scenarios serves as a tool to provide actors with essential understanding, orientation, context, direction, and some degree of consensus in planning research developments and implementations. In relation to ePAL's vision for future, scenarios are used to support understanding of different future possibilities regarding the enhancing of active life of senior professionals, as well as possible actions to take and which events are probable to occur in future. Table 1 summarizes example scenarios established for the ePAL environment.

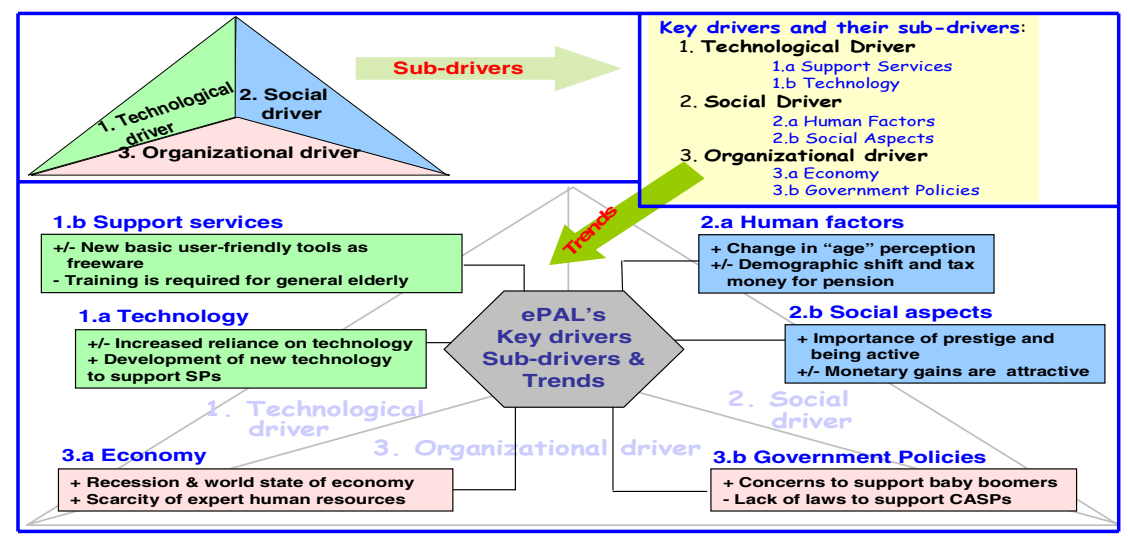

Fig. 4. Drivers and trends for ePAL environment

Table 1. Example scenarios for ePAL environment

\begin{tabular}{|l|l|}
\hline \multicolumn{2}{|c|}{$\begin{array}{c}\text { Mcenario } \\
\text { Category }\end{array}$} \\
$\begin{array}{l}\text { Associations } \\
\text { retired } \\
\text { professionals: } \\
\text { voluntary work }\end{array}$ & $\begin{array}{l}\text { Focusing on the need for communities of active senior professionals to enhance } \\
\text { chances of the involvement of senior professionals in daily activities as volunteers } \\
\text { within their own societies or in other regions. These scenarios address the } \\
\text { establishment, management and operation of the elderly communities. They also } \\
\text { characterize the nature of activities of the communities and roles of senior } \\
\text { professionals in performing those activities. }\end{array}$ \\
\hline $\begin{array}{l}\text { Associations } \\
\text { retired } \\
\text { professionals: } \\
\text { brokerage } \\
\text { launching }\end{array}$ & $\begin{array}{l}\text { Focusing on the role of brokerage of opportunities that can be responded by senior } \\
\text { professionals either individually or through communities of active senior } \\
\text { professionals. These scenarios characterize the roles related to brokering of } \\
\text { opportunities, namely: direct brokerage where senior professionals are involved in } \\
\text { capturing an opportunity or indirect brokerage where a third party is involved in } \\
\text { capturing an opportunity. }\end{array}$ \\
\hline Service markets & $\begin{array}{l}\text { Focusing on potential markets, mostly technology enabled markets, which are } \\
\text { typically feasible for senior professionals to deliver their services. These scenarios } \\
\text { also address the categorization of clients into those who can pay and those who } \\
\text { cannot pay for the services provided by seniors. }\end{array}$ \\
\hline $\begin{array}{l}\text { Tri-partite } \\
\text { collaboration forms }\end{array}$ & $\begin{array}{l}\text { Focusing on different roles that need to be performed by different parties to realize } \\
\text { the establishment and operation of communities of active senior professionals. As } \\
\text { such these scenarios first characterize different stakeholders of the ePAL and then } \\
\text { define the roles of each category of actors. }\end{array}$ \\
\hline $\begin{array}{l}\text { Keeping the link to } \\
\text { former employer }\end{array}$ & $\begin{array}{l}\text { Focusing on existing practices regarding keeping communication with the former } \\
\text { employers and how it enhances the professional activeness of senior professionals. }\end{array}$ \\
\hline Second job & $\begin{array}{l}\text { Focusing on the need for establishing some form of payments for the involvement of } \\
\text { senior professionals in market and society activities. }\end{array}$ \\
\hline
\end{tabular}


From the results of the above two processes - identification of the drivers and trends related to the ePAL vision, and building of scenarios for potential cases, both the potential of the ePAL as well as its main constituents and limitations become evident.

One outcome of this extensive analysis is that we reached a good understanding of what which is necessary to properly "model" this environment. The achieved understanding is in relation to characterization of actors and their roles, as well as behaviour of stakeholders of the ePAL as influenced with both internal factors (membership, bylaws, value systems, etc.) and external factors (market regulations, government policies, intermediary roles, etc.)

Based on the results of the characterization of main elements of ePAL through building scenarios, analysis of trends and drivers, and study of baseline as well as based on the experience of the research consortium which was gained while performing the above processes, we were able to define the main elements of the $1^{\text {st }}$ vision for the ePAL. We defined the vision by matching these results to the definition and components of a vision as described in section 2.1. Thus the main output of this step is therefore the elaborated $1^{\text {st }}$ vision statement for ePAL. The next three steps are summarized in table below.

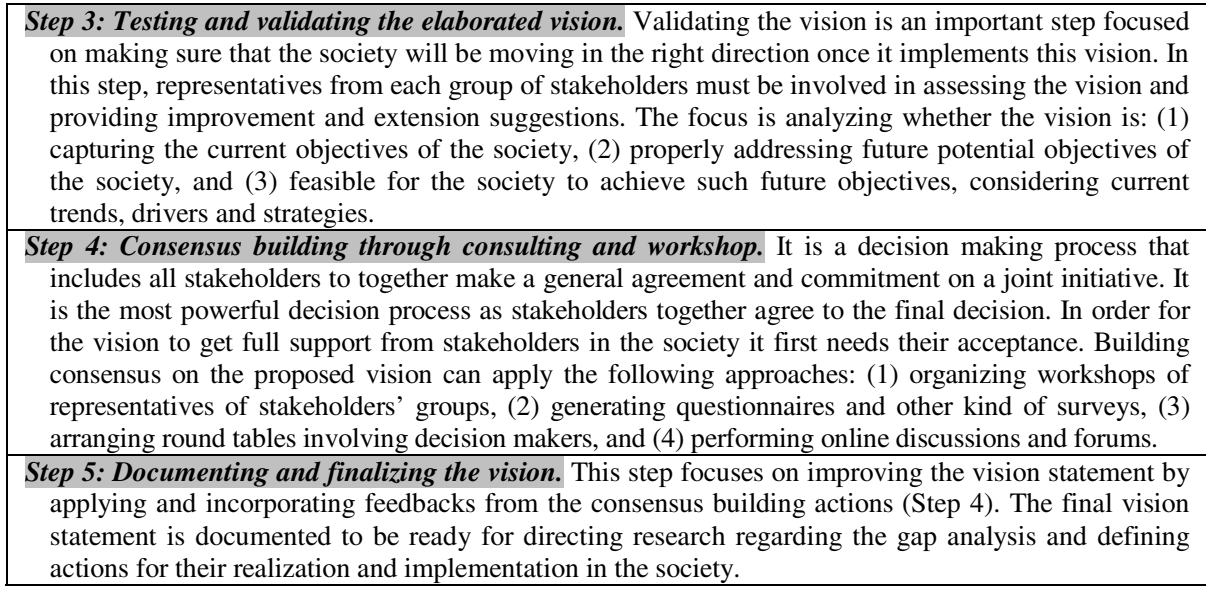

\section{4 ePAL Vision for European Society}

Establishment of ePAL vision. Following the approach presented in Section 3 and also based on the analysis of the current practices and the related literature (consolidated baseline), the drivers and trends in market and society, and the plausible scenarios of future, we have elaborated and formulated the $1^{\text {st }}$ desired vision for ePAL, as shown in Fig. 5.

This vision statement provides a direction where the European society shall strive to follow, in order to achieve a balanced life for senior professionals who either need or desire to remain active in the society. It addresses providing opportunities and support for senior professionals who are willing to get involved in socio-economic activities. On the other hand, it suggests the main areas needing attention from other stakeholders in order to reach this desired state, such as (1) research institutions to 
provide innovative and new ideas in areas which require more $R \& D$, (2) regulatory bodies (e.g. governments, law chambers, judiciaries) to provide a regulatory and legal infrastructure for the involvement of senior professionals in markets, (3) intermediaries (e.g. non-profit organizations, etc.) to support the brokerage of opportunities for senior professionals, etc.

Clearly enough, the creation of a desired vision for ePAL for the next decade is not a one shot action rather it is a live and interactive process. To develop the $1^{\text {st }}$ vision statement for the ePAL environment we have followed a systematic approach, as presented throughout this paper. In the same manner, for the challenging task of $\boldsymbol{d e}$ fining the vision statement itself, we applied the classification proposed by Cumming [4] for defining a well-conceived vision, as addressed earlier in Section 2.1. We therefore piece by piece define the needed conceptual elements for the well-conceived vision for ePAL environment.

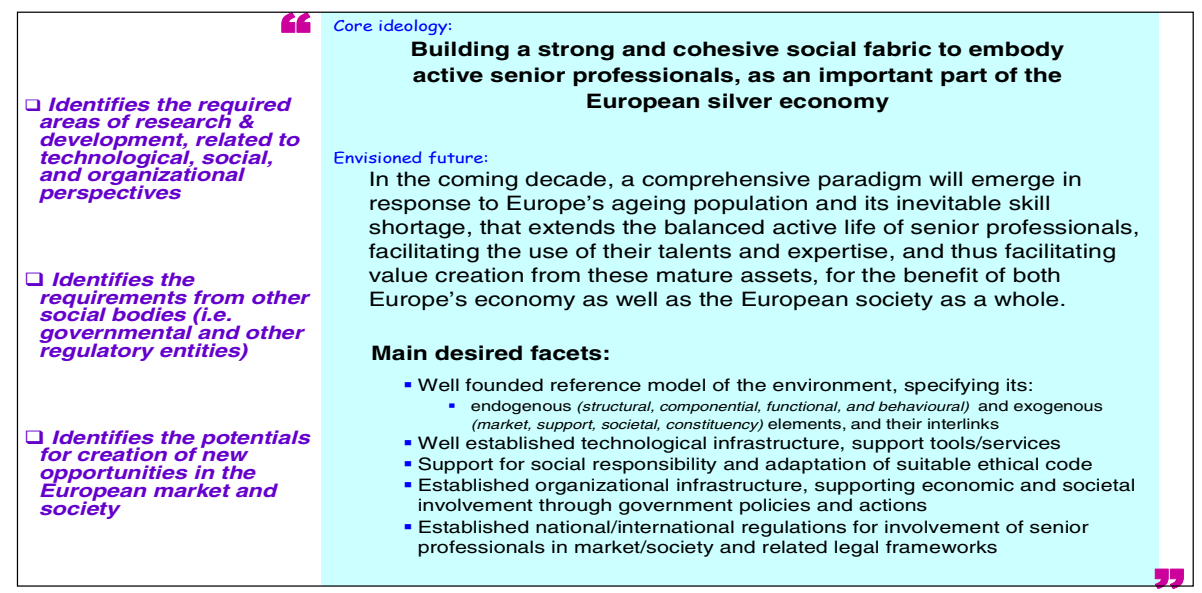

Fig. 5. $1^{\text {st }}$ desired ePAL vision for European society

Below first each such element of this vision is defined and then they are integrated to form the " 1 st vision statement for the ePAL environment for Active Ageing Society", as shown in Fig. 5. The vision elements are presented in Table below.

\begin{tabular}{|c|c|}
\hline $\begin{array}{l}\text { Main } \\
\text { element }\end{array}$ & Sub-elements and descriptions \\
\hline \multirow{2}{*}{$\begin{array}{l}\text { Core } \\
\text { Ideology }\end{array}$} & (1) Core Values: Active senior professionals, as an important part of the European silver economy, \\
\hline & (2) Core Purpose: Building a strong and cohesive social fabric. \\
\hline \multirow[b]{2}{*}{$\begin{array}{l}\text { Envision- } \\
\text { ed Future }\end{array}$} & $\begin{array}{l}\text { (1) Long-term Audacious Goal: In the coming decade, a comprehensive paradigm will emerge in } \\
\text { response to Europe's ageing population and its inevitable skill shortage, that extends the } \\
\text { balanced active life of senior professionals, facilitating the use of their talents and expertise, } \\
\text { and thus facilitating value creation from these senior professionals, for the benefit of both } \\
\text { Europe's economy as well as the European society as a whole, }\end{array}$ \\
\hline & $\begin{array}{l}\text { (2) Vivid description: (a) Well founded reference model of the environment, specifying its } \\
\text { endogenous (structural, componential, functional, and behavioural), and exogenous (market, } \\
\text { support, societal, constituency) elements, and their interlinks, (b) Well established technological } \\
\text { infrastructure, support tools/services, (c) Support for social responsibility and adaptation of } \\
\text { suitable ethical code, (d) Established organizational structure (collaborative network), } \\
\text { supporting economic and societal involvement through government policies and actions, and } \\
\text { (e) Established national/international regulations for involvement of senior professionals in } \\
\text { market/society and related legal frameworks }\end{array}$ \\
\hline
\end{tabular}


Further to the core ideology and the envisioned future, represented inside the quotes, within the definition of vision for ePAL environment, on the left side of the Fig. 5 the three main outcomes of the vision are also listed, namely: (i) identifying required areas for $R \& D$, (ii) identifying the requirements from other social bodies such as governmental and other regulatory entities that requires their attention, and (iii) Identifying the potentials for creation of new opportunities.

Instantiation of the vision into multi-disciplines. We base on multi-perspective concepts to instantiate the formulated vision into the three identified perspectives in order to capture fundamental societal and economical activities that senior professionals shall be involved in daily manner. We also base on the visioning approach that

Table 2. Instantiation of the ePAL vision into the three perspectives

\begin{tabular}{|c|c|c|c|}
\hline \multicolumn{4}{|c|}{ Vision instantiation statement } \\
\hline Technological & \multicolumn{2}{|c|}{ Social } & Organizational \\
\hline $\begin{array}{l}\text { In the coming decade, the ICT } \\
\text { collaboration platforms and tools } \\
\text { will be developed as an easy to use } \\
\text { enabler of new approaches for } \\
\text { continuation of the active } \\
\text { involvement of elderly people in } \\
\text { the socio-economic system. As } \\
\text { such novel infrastructures and } \\
\text { intelligent functionalities will act as } \\
\text { a catalyst of new organizational } \\
\text { forms, supporting effective } \\
\text { management of geographically } \\
\text { disperse communities of retired } \\
\text { professionals, and facilitating the } \\
\text { active participation in the socio- } \\
\text { economic activities, as an extension } \\
\text { of the human capabilities towards } \\
\text { fitted participation. }\end{array}$ & \multicolumn{2}{|c|}{$\begin{array}{l}\text { In the coming decade, extending active } \\
\text { professional life will be a high priority } \\
\text { strategy in addressing Europe's aging } \\
\text { population. The social infrastructure will } \\
\text { mature to accommodate demographic shifts } \\
\text { through the creation of mechanisms to } \\
\text { support active involvement of elderly people } \\
\text { in the silver economy. Attitudes in society } \\
\text { will evolve towards positive acceptance of } \\
\text { elderly people as a value-creating pool of } \\
\text { talent, thereby creating opportunities to } \\
\text { support and promote active aging. Both } \\
\text { senior and young professionals will derive } \\
\text { greater benefit from the exchange of } \\
\text { knowledge and experience. As the social } \\
\text { environment evolves, new support } \\
\text { mechanisms will arise to sustain an aging } \\
\text { but more active and inclusive population. }\end{array}$} & $\begin{array}{l}\text { In the r roming } \\
\text { decade, the primary } \\
\text { stakeholders } \\
\text { government, } \\
\text { intermediate, business, } \\
\text { - will adopt positive } \\
\text { and proactive policies } \\
\text { and approaches that } \\
\text { enable r senior } \\
\text { professionals to } \\
\text { continue their active } \\
\text { life and generate } \\
\text { income that } \\
\text { compensates rar for } \\
\text { pension shortfalls and } \\
\text { facilitates a valuable } \\
\text { contribution r to } \\
\text { Europe's economy. }\end{array}$ \\
\hline \multicolumn{4}{|c|}{ Main desired facets } \\
\hline Technological & Social & \multicolumn{2}{|c|}{ Organizational } \\
\hline $\begin{array}{l}\text { - } \begin{array}{l}\text { Advanced collaboration support } \\
\text { services, including } \\
\text { teams formation }\end{array} \\
\text { management. and } \\
\text { - Support for user-generated } \\
\text { knowledge content. } \\
\text { - } \text { Configure yourself "based } \\
\text { philosophy infrastructure. } \\
\text { - Easily adaptable and } \\
\text { customizable user interfaces. } \\
\text { - Affective computing and } \\
\text { context aware enriched } \\
\text { environments. } \\
\text { - Tools supporting the process of } \\
\text { value creation. } \\
\text { - Novel contractual and } \\
\text { cooperation agreements, } \\
\text { including negotiation support. } \\
\text { - Advanced marketing and } \\
\text { brokerage services. } \\
\text { - New networking models for } \\
\text { elderly a communities' } \\
\text { involvement with the socio- } \\
\text { economic system. }\end{array}$ & $\begin{array}{l}\text { New mechanisms to } \\
\text { enhance positive } \\
\text { understanding and } \\
\text { perception in the society } \\
\text { regarding the value of } \\
\text { abilities, skills and } \\
\text { experience of senior } \\
\text { professionals in the } \\
\text { economy. } \\
\text { Motivation tools for senior } \\
\text { professionals to join elderly } \\
\text { associations. } \\
\text { Mechanisms to support for } \\
\text { cross-cultural interactions } \\
\text { among senior professionals } \\
\text { as well as to the active } \\
\text { labor force. } \\
\text { Mechanisms to support a } \\
\text { balanced economical } \\
\text { benefits sharing among the } \\
\text { entire society including } \\
\text { senior professionals. }\end{array}$ & $\begin{array}{l}\text { - Employment an } \\
\text { change to prov } \\
\text { seniors to continu } \\
\text { - Global regulation } \\
\text { encourage the pa } \\
\text { collaboration witl } \\
\text { - The knowledge a } \\
\text { harnessed to gen } \\
\text { innovation amons } \\
\text { - New forms of int } \\
\text { provide highly e } \\
\text { help seniors en } \\
\text { Europe. } \\
\text { - There will be sig } \\
\text { from both public } \\
\text { the political driv } \\
\text { senior associatio } \\
\text { brokers. } \\
\text { - New organizatio } \\
\text { embrace relatic } \\
\text { professionals } \\
\text { professionals. }\end{array}$ & $\begin{array}{l}\text { retirement policies will } \\
\text { e greater flexibility for } \\
\text { as economic actors. } \\
\text { and polices will change to } \\
\text { ticipation of businesses in } \\
\text { senior professionals. } \\
\text { d skills of seniors will be } \\
\text { rate wealth and stimulate } \\
\text { t European businesses. } \\
\text { rmediate organizations will } \\
\text { icient brokerage that will } \\
\text { tage with businesses in } \\
\text { ficant long-term funding- } \\
\text { and private sectors - and } \\
\text { to support new forms of } \\
\text { s and other intermediate } \\
\text { al cultures will positively } \\
\text { iships between senior } \\
\text { pre-retired (active) } \\
\text { di }\end{array}$ \\
\hline
\end{tabular}


was introduced in the VOmap project regarding the "instantiation of the vision statement" to its main focus areas or perspectives [2]. As such, the vision development mechanism applied in ePAL instantiates its vision statement for three main contributing areas, namely: the technological, social, and organizational perspectives. Table 2 summarizes instantiation statements and the main desired facets for each perspective to support realization of the proposed vision.

\section{Conclusion}

In this paper, we have emphasized the need for systematically formulating a vision for the ePAL while involving all stakeholders in different activities. Applying the proposed approach, a $1^{\text {st }}$ vision statement for ePAL is presented. Furthermore we have shown the main focuses related to technological, social and organizational perspectives that need further attentions. For the proposed vision to be realized there is a need for looking into user friendly collaborative ICT services and infrastructures to facilitate both their usage by seniors as well as the interactions between seniors and other stakeholders. Socially, there is a need to enhance the positive perception of the society towards elder people to view them not as a social and economical burden but as wells of knowledge and experience needed in the society. Organizationally, there is a need for reformulating regulations and organizational models to provide opportunities to senior professionals as other actors in the market.

As future work in relation to development of the desired vision for the ePAL environment the following steps can be mentioned: (1) Further refinement and tuning of the $1^{\text {st }}$ ePAL vision, (2) Dissemination and discussion of the ePAL vision, and (3) Achieving the final vision specification for the ePAL environment. Another fundamental aspect that will be addressed by our research is related to the refinement of the areas of $R \& D$ related to the three perspectives of the vision.

Acknowledgement. This work was supported in part by the ePAL project funded by the European Commission. The authors acknowledge contributions from partners in ePAL.

\section{References}

1. Camarinha-Matos, L.M., Afsarmanesh, H.: A comprehensive modeling framework for collaborative networked organizations. The Journal of Intelligent Manufacturing 18(5), 527 615 (2007)

2. Camarinha-Matos, L.M., Afsarmanesh, H.: A roadmap for strategic research on virtual organizations. In: Proceedings of PRO-VE 2003 - Processes and Foundations for Virtual Organizations. Kluwer Academic Publishers, Dordrecht (2003)

3. Collins, J.C., Porras, J.I.: Organizational vision and visionary organizations. In: Leading organizations - Perspectives for a new era, pp. 234-249. SAGE, Thousand Oaks (1998)

4. Cummings, T.G.: Organization Development and Change. Thomson South-Western (2005)

5. Donald, E.H.: Building leadership vision. Eleven strategic challenges for higher education. The EDUCAUSE review, 25-34 (2003) 
6. Hinrichsen, D., Robey, B.: Population and the Environment: The Global Challenge (08/2008),

http: / /www.actionbioscience.org/environment/ hinrichsen_robey.html\#primer

7. Kakabadse, N., Kakabadse, A., Lee-Davies, L.: Visioning the pathway: A leadership process model. European Management Journal 23(2), 237-246 (2005)

8. Laubacher, R.J., Malone, T.W.: Two scenarios for 21 st century organizations: shifting networks of small firms or all-encompassing "virtual countries"? A working paper, MIT, USA (1997)

9. Senge, P., Kleiner, A., Roberts, C., Ross, R., Smit, B.: The Fifth Discipline Fieldbook Strategies and Tools for Building A Learning Organization. Doubleday Publishing (1994)

10. Stranges, M.: Immigration As a Remedy for Population Decline? An Overview of the European Countries. European papers on the new welfare, Special issue on the counter ageing society, paper no. 8 (2008) 